\title{
Creating and Organizing a New Field Decision-Making in the Albanian Legal Framework and European Integration
}

\author{
PhD Ina Foto Barjamaj \\ PhD candidate, Institute for European Studies, University of Tirana, Albania, \\ Email:ina.puravelli@yahoo.com
}

Prof. Alba Robert Dumi

Dean of Graduate School, "Ismail Qemali"Vlore University, Albania, University of Tirana, Albania,Management Department, Email:alba.besi12@gmail.com

Doi:10.5901/ajis.2014.v3n3p523

\begin{abstract}
Reforming the justice system has been the promoter of change and sanctioned way of their regulating. The aim of this paper is the study of the creation and operation of a new field of decision-making, such as the Administrative Court as a court of independent and impartial, established under the law and able to meet the requirements of the development of a fair trial. Challenges facing the court as a young and newly created. Also studying in comparative plan the models of this court that are apply to other European countries. The study aims to highlight the best sides that can be implemented for the model that is selected and approximation with the acquis communautaire in the context of integration. Contributing to the creation of theoretical conditions and more efficient ways to achieve the adoption of European law in general and administrative Europeans in particular that in the Albanian interior. Functioning of the Administrative Court will have an impact on public administration, improved the quality of its services and consequently increase citizen confidence in state institutions
\end{abstract}

Keywords: Human rights, justice reform, the challenges of administrative decision-making, administrative tribunal, EU Criteria

\section{Introduction}

The existence of the rule of law means recognizing and respecting the rights and freedoms of every individual. In this aspect the commitment that the state has taken to its citizens, is helped by the legal framework. Reforming the legal framework is imposed by the frequently changes occurring, which require disciplined by the new rate. The right should regulate relations and not create problems.1 The purpose of this paper is the study of general reform of the legal administrative framework under the framework of justice reform. The state function as an organization and a special role is played by the public administration and not only. Reforms undertaken in particular are focused on public administration, in that are materializes the state policies. To determine its functioning, is sufficient to ask questions about the quality of services offered and how social policies are undertaken. Since it is a very important subject of administrative relations, as the consequence is necessary that the judgment of disputes created during its activity, to be judged by a judicial body that is independent from the administration. Establishment of Administrative Court aims to reduce trial time and disputes procedure by making the process more efficient and increasing the confidence of citizens to the rule of law and justice.

\subsection{Albanian legal framework and European integration}

The Albanian state has faced a number of challenges since the changes of 1990. For this reason has undertaken a series of reforms, from time to time in a rapid way and from time to time in a passive way, having the sole purpose of joining the European family. But was not enough drafting of laws to do so, much more is needed. Its necessary political will and civic awareness. It is first necessary change of mentality and the rebirth of a new leadership, capable of contributing his energy and accountability in law enforcement. The first reformation is closely linked to the legal approximation.

The Stabilization and Association Agreement between Albania and the EU entered into force in April 2009. Albania presented its application for membership of the European Union on 28 April 2009. Following a request by the Council, the

\footnotetext{
${ }^{1}$ Ardian Nuni topics: "Right, justice and us, in these 20 years: Reflections" Conference "Judicial reform causes as a challenge among 12 priorities that the EU integration of Albania" in Tirana, July 2012
} 
Commission submitted its Opinion on Albania's application in November 2010. Liability for approximation of legislation with the EU acquis set out in Articles 6 and 70 of the SAA. Approximation of legislation is a complex process and very demanding. ${ }^{2}$ It requires to Albania, not only to build its regulatory framework in line with the European standards, but also seeks to provide administrative structures and other conditions necessary for the implementation of the acquis. Pursuant to article 70, paragraph 2, has approximation starting from the date of signing of the SAA, 12 June 2006 and finish at the end of the transitional period until 2016 divided into two phases with 5 years each.

From this perspective, reforming requires an extension in time, in order to achieve the desired results. Reform of the justice has been a promoter of change, such is the creation of Administrative Court. The need to have a new field administrative decision-making was born as a result of gaps that were noted in the review of various administrative disputes, to lengthy delays and unjustified. And this particular was made concrete, with the establishment and functioning of the Administrative Court in order to create appropriate conditions for an effective review by restoring the violated rights of action and / or administrative acts issued by public bodies. The need for the creation of the administrative court has not only been a requirement as a condition to be fulfilled in the context of integration, but has been asked repeatedly by interest groups. Beginning of its operation since 04 November 2013 marks a new stage in administrative disputes and also in the administrative decision-making.

\subsubsection{The steps that are followed to the functioning of the Administrative Court}

The existence and functioning of the rule of law is based on an important principle which is of the supremacy of law, the principle of separation and balance of powers ${ }^{3}$. Legal review of administrative decisions by independent courts is an accepted democratic principle, present in major European practices and an important contribution to ensure order, particularly to protect individual rights from the administration. The necessity of creation of a new administrative court, begat as the need of deficiencies, delays and crawling that occur for administrative disputes at the relevant sections, near the district courts.

Table 1: Reasons for postponing the hearings ${ }^{4}$

\begin{tabular}{|lc|}
\hline Judge absent (for health reasons, family, seminars) & $16,5 \%$ \\
\hline To obtain other evidence & $11,9 \%$ \\
\hline Lawyer Absent (for health reasons, family, seminars) & $11,9 \%$ \\
\hline Absent plaintiff or respondent although informed & $10,1 \%$ \\
\hline Absent plaintiff or respondent because they had become aware & $8,3 \%$ \\
\hline Moving from one phase to the other (or she completed preparatory sessions court) & $7,3 \%$ \\
\hline Procedural actions related experts (drafting the act, consultation parties act) & $7,3 \%$ \\
\hline For notice or expert witness & $5,5 \%$ \\
\hline For completion of the flaws we claim & $4,6 \%$ \\
\hline And other & $4,6 \%$ \\
\hline
\end{tabular}

From the birth of the opinion to reform the justice system by creating a new court until its creation has passed a relatively long time. Time that was required for the amendment of the law, his discussion from the groups of interest and the establishment of infrastructure necessary for the implementation of the law. The necessity of this change is imposed mostly by interest groups, who were having lobbied for the creation as the first administrative court. In this way was given more importance to reach an agreement on approving the law rather than the quality that this law should have, so that at the moment that law would enter into force will be possible an effective implementation. For this reason the law No.49/2012 "On the organization and functioning of Administrative Courts and administrative disputes" sets binding rules for administrative adjudication entities, state bodies, legal entities and citizens regarding administrative disputes, enforcement of administrative judgments, as well as the organization of the administrative courts.

\footnotetext{
2 Erion Fejzullah and Aida Gugu Implementation Plan SAA and its importance in the process of European integration of Albania, Bulletin No. 2, March 2012

${ }^{3}$ Article 7 of the Constitution of the Republic of Albania

${ }^{4}$ Drejte drejtesise Aananlize e procesit civil ne gjykata e rretheve gjyqesore, Botuar nga Organizata për Siguri dhe Bashkëpunim në Evropë 2013, faqe 15
} 


\section{Literature Review and Hypotheses}

\subsection{Administrative justice systems at the global level}

In certain jurisdictions, primarily those of common law protection against public administration is delegated, in principle, at the same court that has jurisdiction to judge upon the disputes between the parties (the so-called common system), while in other jurisdictions refers to special courts (administrative courts, which characterize the so-called two level system). There is another model, as is the case of Spain that implements an intermediate solution, leaving the protection of specialized sections to ordinary courts. In a summary, putting forward the characteristics of different models that states implement in their practice of judicial review of administrative acts by a Administrative court and features that each model represents.

\subsection{System of only ordinary jurisdiction}

According to this system, the activity of public administration is subject of the review by the ordinary jurisdiction. This system is characteristic of Anglo-Saxon countries (common law), but is implemented and in other countries like Norway, Israel and some countries of the former Soviet Union. Review of this activity is subject to certain restrictions: reviews issues that are associated with overcoming of competence and the legitimacy (ultra vires), but no power of cancel, suspend or modify an administrative act, the administrative activity and limited only to rendering decisions on reinstatement consequences caused by administrative activities, for example. "Paid the damages" Does not constitute part of judicial jurisdiction, issues that entered in jurisdiction of the administrative settlement, and usually have these attribute special committees with administrative character.

\subsection{System of dual jurisdiction (of ordinary and administrative)}

According to this system, review of administrative activity remains under the jurisdiction of the ordinary courts as to the judgment of administrative disputes while jurisdiction for the annulment of illegal administrative acts is reserved to the organs who exercise administrative jurisdiction, formally part of the public administration, but at the same time independent, because they enjoy the status of a judge. It is the system adopted in most of Europe (Italy, France, Belgium, Austria, Germany, Switzerland, Denmark, Greece, etc.) as well as in Latin America (Uruguay, Colombia, and Panama). Bodies of administrative jurisdiction are usually central, with power lying in of entire state territory, for example. "Consilio di stato in Italy, the Conseil d'Etat in France and Belgium, Bundesverwaltungsgericht in Germany" But there may be peripheral bodies of the administrative jurisdiction, eg. "Tribunal's admistratifs regionals in France"

\subsection{Specialized jurisdiction system}

According to this system, there are at every level of the ordinary courts, specialized sections for administrative dispute resolution. An intermediate system between the two systems mentioned above is implemented in Spain. Such sections are formed by $1 / 3$ of ordinary judges, $1 / 3$ of administrative judges and $1 / 3$ of public administration specialist. These sections are included in the judicial system.

H1: There are a number of problems that arise and that may arise in the practice of administrative courts. Among the most significant is the problem of delay of the procedures and so citizens lose faith in the courts.

Given that in the law that establishing the administrative court were no transitional provisions then in the unifying decision No.3 dated 12.06.2013 the Supreme Court unified the case law by deciding that all issues that were examined by an ordinary court will be review due to lack of jurisdiction by the administrative tribunal. So number of cases that defined by law were added issues that were transferred from district court and court of appeal. One of Principal problems currently facing the new administrative court is the sheer volume of issues you should judge because once these issues have been dismissed by the ordinary courts, due to lack of jurisdiction. Thereby the work of these courts is increased sharply, while the administrative staff is not completed properly consolidated, creating an unfavorable situation for the citizens, who have addressed their administrative dispute to this court for an efficient solution.

H2: Another problem relates to the inability to appeal the decisions of the administrative courts

Under the provisions of Article 45 and 46 of Law nr.49/2012 has classified a set of issues that due to the small value of the object of the claim cannot be appealed to a higher degree. If this value is smaller twenty times the national minimum wage, the Administrative Court of Appeal did not accept the case for review. In the same way also operates 
College Administrative High Court in relation to matters in which the value of the research or of the right is less than forty times the national minimum wage.

This new regulation is restrictive in nature compared with the previous regulation of the Code of Civil Procedure 5 to allow the right of appeal or recourse, regardless of the value of research or law that was subject to review before the court.The right of appeal and to access to the court and are not absolute and unlimited. They may be subject to restrictions by the legislature, only by respecting the principle of proportionality. Setting this threshold in the value of the claim, as a condition to exercising the right of appeal, was to avoid the overload of administrative disputes trials with small value and ending them in the first instance.

H 3:No institutional regulation of administrative conflict, there isn't a full definition of administrative conflict and not expanding enough of supervision of legality in all individual acts of state government and public.

These courts are responsible for administrative issues which, claim, appeal or recourse is deposited before $11 / 04 / 2013$, respectively in the courts of first instance, on appeal or to the Supreme Court and by this date, the review did not finished ". What problems might arise in the practice of administrative courts? Should be reviewed when is excluded the appeal of the decision of administrative court, although recent practices are favorable and, in principle, provide for appeal of decisions of administrative courts. It may also be mentioned that some countries in efforts to harmonize their legislation with the provisions of the Convention for the Protection of Human Rights and Fundamental Freedoms. In these efforts, faces an insufficient degree of harmonization of administrative conflicts with the overall document. In connection with administrative conflicts themselves, appear and may show different problems. In a summary encountered these problems: No institutional regulation of administrative conflict, no decentralization, no leadership up to bottom.

\subsection{Indirect protection system, the protection and individual rights}

The law no.49/2012 is published in the Official Journal No. 53 of 2012 and entered into force on 30 May 2012, ie 15 days after publication in the Official Journal, as predicted in its Article 73. In application of Article 70/5 of Law 49/2012, based on the proposal of the Minister of Justice, the President of the Republic has issued the Decree no. 8349, dated 10.14.2013, which has set the date $04 / 11 / 2013$ as the starting day functioning of the administrative courts. This date marked the beginning of full effects of legal and law enforcement in general $\mathrm{nr} .49 / 2012$ regarding jurisdiction and procedure of trial of issues subject to administrative disputes mentioned in Article 7.

The problem is that the law of Administrative Court had not explicitly define that which is the competent court for review of administrative disputes that the lawsuit, the appeal or the recourse is deposited before the date 04/11/2013 in the first instance court, in the Appeals or at the High Court. So the Supreme Court took over to unify the judicial practice. So according to unifying decision of the High Court dated 06.12.2013 No. 3 who has decided that: "Administrative Courts of First Instance, the Administrative Court of Appeals and the Administrative Panel of the Supreme Court, established by Law No. 49, dated 03.05.2012 "On the organization and functioning of administrative courts and administrative disputes ", are responsible for review of all issues, which under Article 7 of this law constitute administrative dispute, despite the situation, phase or stage of the trial.

But according to Vlora District Court, the High Court has overcome the powers given by law in the interpretation that has been made in unifying decision.

By Vlora District Court was suspended the control of legality of an administrative act, and wasn't declared noncompetence according to the unifying decision of the Supreme Court. For this reason was asked the Constitutional Court to rule on the constitutionality of unifying decision No.3 dated 12.13.2013 of the High Court because touch the Article 6 and 42 of the constitution. With the argument that this decision violates the principle of legal security by giving retroactive effect to the law of Administrative Court as the effect of the action extends also to those issues that were pending before the date $11 / 04 / 2013$.

\subsection{The best model to be implemented}

There may be an ideal solution, an effective judicial system with broad jurisdiction over each circle and at the same time more special judges.

The best solution possible might be a fair compromise in balancing the interests of the opposite, and also considering the possibility of achieving in practice.

Administrative judiciary is widespread in European Union countries. According to the state in 2007, the 16

${ }^{5}$ The Unifying decision dated 06.12.2013 No.3 High Court 
countries of the European Union, from a total of 27 members, as in Germany, Austria, Belgium, Finland, France, Greece, Italy, Latvia, Luxembourg, Netherlands, Poland, Portugal, Czech Republic, Sweden, Romania and Bulgaria, the administrative courts operate as specialized courts. In 11 other states member of the European Union, as Estonia, Denmark, Ireland, Lithuania, Hungary, Malta, Spain, Slovenia, Slovakia and the UK, operating subsidiaries or specialized rooms for administrative law, in the framework of high courts (supreme).

Perhaps there is no a perfect model because if a model is successfully in one place he cannot be efficient in another country as conditions doesn't allow to well-functioning. Albanian legislator has chosen as the best models the ordinary court to judgment the administrative disputes, after testing it for a period of 17 years; the time testified that change was needed. As an alternative of improvement and reformation were found the creation of special administrative courts. If this was the right solution or the right model that should be adopted, the time will prove.

\subsection{Research Goal}

In this survey we aim to identify the mediating effect of Albanian practice of law progress, autonomous administrative jurisdiction and decision making under EU considerations. In this line is the situation presented with the establishment of administrative courts. Administrative tribunals were created to resolve disputes between legal entities, individuals and state administration within a shortest time, setting the deadlines for each degree of judgment.

Referring unifying decision of the Supreme Court should be kept in consideration some important principles. Main principles governing the justice system are the principle tribunal established by law ${ }^{6}$, principle of trial within a reasonable time and the principle of legal certainty. The right of each party to be heard at a hearing before a court of competent jurisdiction requires that the court has jurisdiction to hear the case and that the powers is given to her by law. ${ }^{7}$

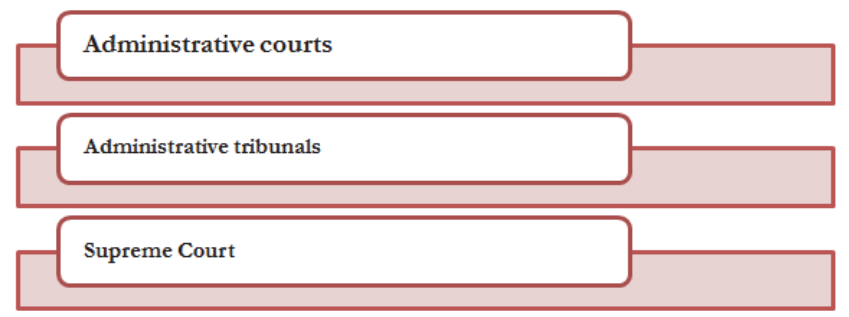

Source: Barjaba, K \& Elbasani, A. (2004, June). Albania in transition: Manipulation or appropriation of international norms. Southeast -European Politics Vol. V. No.1, pp. 24-44. Retrieved from Southeast European Politics, 2004 seep.ceu.hu archives/issue51/elbasani.pdf

Continuation of trial by the same panel constitutes a guarantee for the respect of the principle of due process, that of the "tribunal established by law." Legal certainty, which is derived from the Constitution and by the general principles of law. Legal certainty is one of the essential elements of the rule of law and it certainly presupposes, among other things, public confidence in the state and the immutability of the law regulated relations. Principles which should guide the work of the new court established that administrative.

Court which was in its beginnings faces a series of problems to be solved, therefore required the creation of a legal practice which will consolidate the function mode and will better orient parties in administrative disputes. Seen in the light of the above principles the Constitutional Court must change the unifying decision after trial recently by administrative courts will cause the change of rules of procedure under the provisions of the new Law 49/2012. This brings up another psychological condition of the parties, which infringed on their legitimate expectations and their faith in the state and effective justice ${ }^{8}$.

\footnotetext{
${ }^{6}$ See Decision No. 7, dated 09.03.2009 of the Constitutional Court.

7 See Decision No.31, dated 01.12.2005 of the Constitutional Court.

8 The Unifying decision dated 06.12.2013 No.3 High Court
} 
Source: Dumi, A. (2013, November). Albania and EU reforming in economy and public Administration, MJERSS Roma Italy Vol.5.No 3, pp 234

\subsection{What will be expected of judicial control in Albania?}

Nothing more and nothing, less than: what it offers, in fact, judicial control. Perhaps it would be better to ask, what judicial review is looking from Albania judiciary? 1) Judicial control in Albania requires a decision (judgment) at the optimal time and not only wide volume control. 2) Effective measures in judicial protection. 3) Sufficient degree of intensity' in control of public decisions, including the full review of the facts and full respect of fundamental principles.

But now with the entry into force of the law has not any hesitation that the model that is chosen by the Albanian legislatures is that of an autonomous administrative jurisdiction which is not integrated into the ordinary judicial system, as previously functioned. Although passed a long time, from the moment that filed the necessity of establishing administrative courts until entry into force of this law the first problems occur again. Often happens in Albanian practice that with the only intention to be part of the European Union, we should approve as many laws, without aimed that this legislation should be sustainable, long-term and respond to requests for development?.

\section{Conclusions and Recommendation}

Creating of administrative court brought a new field in the framework decision on judicial reform aiming a trial within a reasonable time. Now with the adoption and entry into force of the Law on Administrative Courts have an innovative new field in the justice system. The administrative tribunals were created to resolve disputes between legal entities, individuals and state administration within a shortest time, setting the deadlines for each degree of judgment. One of Principal problems currently facing the new administrative court is the sheer volume of issues that should be judge because once these issues have been dismissed by the ordinary courts, due to lack of jurisdiction.

The new regulation is restrictive in nature compared with the previous regulation of the Code of Civil Procedure to allow the right of appeal or recourse, regardless of the value of research or law that was subject to review before the court. Another issue is the impact of the international legislation in the approval of the Administrative Court Law, especially in determining the minimum standards for judicial control of the administration. Still more needs to be done, other challenges facing the Albanian justice system such as guaranteeing the independence, credibility and access to court.

\section{References}

Barjaba, K \& Elbasani, A. (2004, June). Albania in transition: Manipulation or appropriation of international norms. Southeast -European Politics Vol. V. No.1, pp. 24-44. Retrieved from Southeast European Politics, 2004 - seep.ceu.hu archives/issue51/elbasani.pdf

Bushati, D: Author. Retrieved from Freedom House, website - site at www.freedomhouse.hu/nitransit, Organization database /2008/albania2008.pdf.

Dumi, A. (2013, November). Albania and EU reforming in economy and public Administration, MJERSS Roma Italy Vol.5.No 3, pp 234

Dumi, A.(2013, March). The democratic movement in Albania, pp 345, MJERSS Roma Italy Vol.1.No 2, pp

Freedom House Report (2008 October). Nations in Transit 2008, Albania (Freedom House publication 23 June 2008)

Goldman F., M. (1997). Revolution and Change in Central and Eastern Europe; political, economical and social challenges.

Nuni A ( 2012) Gjyqtar i Gjykatës së Lartë punimi “Edrejta, drejtesia dhe ne, ne 20 vjet refleksione" ne Konferenca "Reforma gjyqësore si një ndër 12 prioritetet e sfidës së integrimit të Shqipërisë në BE Tirana Albania

\footnotetext{
${ }^{9}$ Ardian Nuni topics: "Right, justice and us, in these 20 years: Reflections" Conference "Judicial reform causes as a challenge among 12 priorities that the EU integration of Albania" in Tirana, July 2012
} 


\section{Laws Recommended}

Institucions Administratives 4e edition , LG,D,J Kodeks RSEFR per aktin dhe kundravajtietnadministrative, nr 13, f 9

Ligji "Për organizimin dhe funksionimin e administratës shtetërore"

Ligji nr 8485, datë 12.05.1999, Fletore Zyrtare nr 19, viti 1999, fae 591-592

Ligji nr.8485, datë 12.05.1999 "Kodi i Proçedurave Administrative të Republikes së Shqipërisë

Kodi i Proçedurës Civile, Botim i Qëndrës së Publikimeve Zyrtare, 1996

Ligji Nr. 8346, dt: 28. 12. 1998 "Mbi Organizimin e Pushtetit Gjyqësor në Republikën e Shqipërisë"

Ligji nr.7491 dt: 29. 04. 1991 "Për dispozitat kryesore kushtetuese"

Relacion për projektligjin "Për gjykimin e mosmarrëveshjeve administrative dhe organizimin e drejtësisë administrative",www. justice. gov. Al Sadushi, S. , Ibrahimi, G. "Komentari i Kodit të Proçedurave Administrative”, Instituti për studime publike \& ligjore, Tiranë, 2000.

(http://193.191.217.21/en/home_en.html).

Vendimi Unifikues Nr.3 date 06.12.2013 i Gjykates se Larte

Vendimi Unifikues Nr.3 date 10.01.2008 i Gjykates se Larte

Vendimi i Gjykatës Kushtetuese nr.16, datë 11.11.2004

Vendimin e Gjykatës Kushtetuese nr. 25, Datë 13,02,2002

Vendimin e Gjykatës Kushtetuese nr.9, Datë 26.2.2007, Botuar në fletoren Zyrtare

Vendimin nr.106/2002; nr.11/2009 të Gjykatës Kushtetuese 